\title{
Pesticide Use Pattern among Farmers in a Rural District of Meknes: Morocco
}

\author{
Berni Imane $^{1 *}$, Atassi Mariam², Nejjari Chakib², Zidouh Ahmed³, El Jaafari Samir ${ }^{1}$, El Rhazi Karima² \\ ${ }^{1}$ Health-Environment Cluster, Faculty of Science, Moulay Ismail University, Meknes, Morocco \\ ${ }^{2}$ Laboratory of Epidemiology, Clinical Research and Community Health, Faculty of Medicine and Pharmacy, \\ Sidi Mohamed Ben Abdellah University, Fez, Morocco \\ ${ }^{3}$ Lalla Salma Foundation, Cancer Prevention and Treatment, Rabat, Morocco \\ Email: ^Imane.berni@gmail.com, mariammarocfes@hotmail.com, cnejjari2000@yahoo.fr, ahmed.zidouh@alsc.ma, \\ s.eljaafari@gmail.com, elrhazikarima@gmail.com
}

How to cite this paper: Imane, B., Mariam, A., Chakib, N., Ahmed, Z., Samir, E.J. and Karima, E.R. (2016) Pesticide Use Pattern among Farmers in a Rural District of Meknes: Morocco. Open Access Library Journal, 3: e3125.

http://dx.doi.org/10.4236/oalib.1103125

Received: October 9, 2016

Accepted: December 4, 2016

Published: December 7, 2016

Copyright $\odot 2016$ by authors and Open Access Library Inc.

This work is licensed under the Creative Commons Attribution International

License (CC BY 4.0).

http://creativecommons.org/licenses/by/4.0/

(c) (i) Open Access

\begin{abstract}
Background: Pesticides in Morocco are extensively used for pest control in agriculture. Their usage practices may potentially result in high farmer exposures and adverse health effects. The objective of this study is to evaluate the risks to human health phytosanitary practices of rural farmers in the region of Meknes. Methods: This study was based on a transversal survey dealt with 402 farming households in 15 rural communes. The results of the survey have undergone statistical analysis. Results: A sample of 402 individuals were included in this survey; it was found that the age of the farmers surveyed is between 18 and 72 years. The potato vine crops and orchards record the most important use pesticides. The survey found that $74 \mathrm{com}$ mercial preparations are used, 14 insecticides, 23 fungicides, 26 herbicides, 3 insecticide-acaricide and 1 nematicide. Some of these substances are classified as to its carcinogenicity risk in group $1,2 \mathrm{~A}$ and $2 \mathrm{~B}$ according to IARC monograph (International Center for Research on Cancer). The farmers use carcinogens products: $47.3 \%$ are already exposed to tobacco, and very few of these producers are confronted with the health rules for the phytosanitary treatment. Most reported that they have skin irritation after application of pesticides, a cold and hot flushes and other health problems such as respiratory problems including "allergies". No significant correlation was found between the declaration of these health problems and the level of education. Among the farmers who reported these problems, 3.73\% reported having headaches, and eleven having respiratory problems. The consumption of alcohol and tobacco to a certain degree had a strong correlation with the return of these health problems ( $p$ $=0.0057$ and $p=0.052$ ). Conclusions: This study shows that farmers in Meknes region are frequently exposed to dangerous and restricted pesticides, practicing their agricultural activities within adequate protection. The study establishes a diagnosis of
\end{abstract}


farmers' exposure to carcinogenic chemicals and is an important basis for the definition of preventive measures against the risk factors linked to cancer in the farms.

\section{Subject Areas}

Epidemiology

\section{Keywords}

Carcinogenic Pesticides, Farmer, Risk, Meknes

\section{Background}

Pesticides are intended to fight against crop pests, whether insects (insecticides), mold/diseases (fungicides) or plants (herbicides). Agriculture is the sector of activity using the most pesticides in Morocco. Globally, the rise in pesticide sales reached 15\% on average. It increased by $24 \%$ in Africa, $20 \%$ in Latin America, $16 \%$ in Asia and $6 \%$ in North America in recent years (http://www.pleinchamp.com).

In Morocco, the import, manufacture, sale, distribution or even for free of agricultural pesticides products is subject to conditions stipulated by Law 42 - 95 and its implementing decrees. The lack of manufacturing units that $95 \%$ of pesticides are imported ready for use (on average 17,519 tonnes/year in 2009). As against $35 \%$ to $45 \%$ of what is imported is repackaged in small packages tailored to meet the needs of small farmers [1]. According to the Moroccan Association of Importers traders and formulators of pesticides (AMIPHY) over 600 commercial preparations are imported and marketed in Morocco. The tonnage of pesticides is increasing since 2005 [1], it is of the order of 17,519 $t$ in 2009 [2], with 831 commercial specialties pesticide active ingredients and 320 were identified [1]. Insecticides come first, with percentages ranging from $35 \%$ to $40 \%$, followed by fungicides with $35 \%$, followed by the herbicides that can oscillate between $10 \%$ and $15 \%$ depending on the year and weather conditions [1] Note that an estimated market share of between $10 \%$ and $15 \%$ is from the smuggling and counterfeiting [3].

However, if the use of pesticides is regarded for years as the most cost effective means of control, the profit margin is significantly reduced by subtracting the cost of their adverse effects on the environment, birds, natural enemies and human health [4]. Pesticides have all, to varying degree, potential toxicity and unfortunately can be toxic to non-target organisms, including humans [5].

Today, these environmental pollutants represent a serious public health problem through two aspects: 1) they can cause toxicity in humans and ecosystems; 2) the risk of diseases that the use or exposure to these substances and their derivatives can cause [6] [7]. Twenty-one pesticides identified as a result of the last IARC study showed significant associations with exposure-effect in the impact of specific cancers while controlling the main potential confounders [8]. 
By their serious side effects on human health and the environment, pesticides are suspected to cause serious effects on consumers, users or contaminated in general [9] [10]. The recent collective expertise "Inserm" Pesticides: occurrence of certain cancers, neurodegenerative diseases and endocrine disturbances, decreased mental capacity, abnormal reproduction with abortions [5] [11] and modification DNA [12]. Approximately $54 \%$ of poisoning cases are related to agricultural pesticides [13]; these poisonings area source of significant morbidity and mortality. Indeed, according to the World Health Organization, the annual number of pesticide poisonings is between 1 and 5 million, of which several thousand cases of deaths are fetuses, children, infants and the elderly who are the most sensitive [5].

In Morocco, cancer is the second cause of death with a prevalence of $3.2 \%$ in children [14]. The retrospective study based on data toxicovigilance CAPM-PV, over a period of 19 years (1989-2007) has identified 10332 cases of acute pesticide poisoning (IPA) [15]. And In another epidemiological study of cases of fatal poisoning led by the Poison Control Center and Pharmacovigilance of Morocco, during the period1992-2009, pesticides are the second category of toxic agents causing death with a percentage of $20.8 \%$ and organochlorine pesticideswith19.54\% [16]. While in the region of Meknes a filalet, it is estimated that $11.2 \%$ cases of pesticide poisoning occur among agricultural workers each year with about $4.6 \%$ of deaths [17]. A Moroccan study identifies poisoning organophosphate pesticides as a real health problem in Morocco [17]. Pesticide exposure may be by the skin, respiratory tract and oral whose risk generally increases with increasing dose.

A literature search revealed that there's little research in Morocco for the assessment of health risks associated with exposure of farmers to pesticides. Our study was conducted against that backdrop to explore the use of pesticides and the key model carcinogens among farmers in the rural region of Meknes-El Hajeb with an attempt to identify gaps in their knowledge and awareness about the risks and dangers of pesticide use on human health and the environment.

\section{Methods}

\subsection{Study Design and Setting}

This was a cross-sectional study carried out among farmers in 15 rural communities namely: Ait Oualal Ait Khelfen, Aït Yaazem, Dar Oum Sultan Dkhissa, Iqaddar, Laqsir, Mghassine, Nzalat, Wad Jdida, Oualili, Oued Rumani, Jerry Rass, Khayate (Figure 1) in Meknes El Hajeb region in north-eastern Morocco in 2008 (Table 1).

Table 1. Characteristics of the regions covered by the study.

\begin{tabular}{ccccc}
\hline Region & Altitude $(\mathrm{m})$ & Latitude (North) & Longitude (west) & Climate \\
\hline Meknes & 552 & $33^{\circ} 53^{\prime}$ & $5^{\circ} 33^{\prime}$ & Mediterranean \\
El Hajeb & 1000 & $33^{\circ} 41^{\prime}$ & $5^{\circ} 22^{\prime}$ & Semi-arid temeprate winter \\
\hline
\end{tabular}




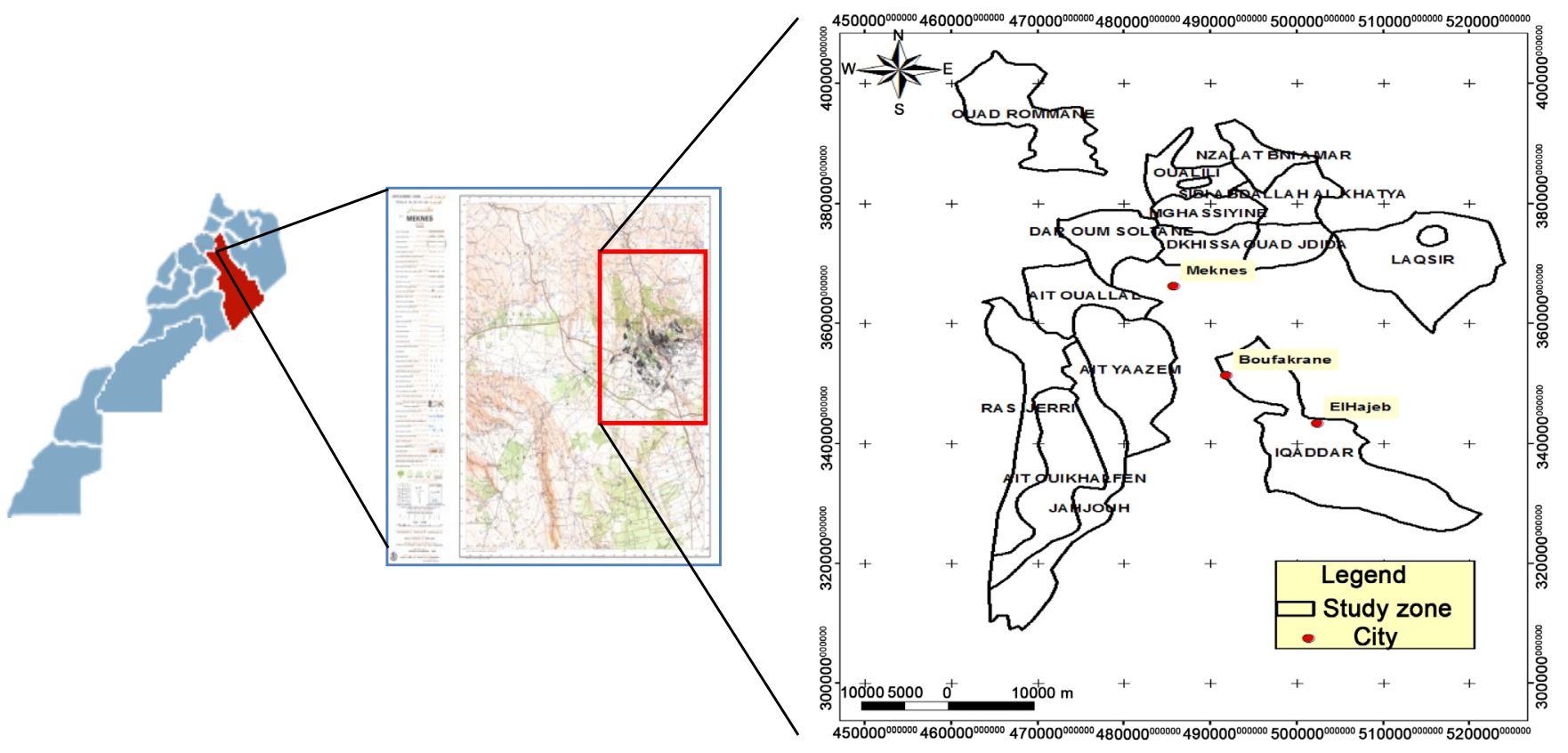

Figure 1. Location of the study area.

Data from the synthesis report on the activity and employment in 2006 of the Department of Statistics, the High Commission for Planning in Morocco were used to select regions of the conduct of the study. This area was chosen for the reason that the Meknes region is an important agricultural region of Morocco, known for the use of fertilizers, insecticides, and pesticides.

\subsection{Sample Size}

The sample size was arrived at using data from the summary report on the activity and employment in 2006 of the Department of Statistics, the High Planning Commission in Morocco and the formulas and conditions following:

The number $(\mathrm{N})$ is calculated using the following formula (for very large populations):

$$
N=\Pi \times(1-\Pi) \times\left(\frac{Z_{\alpha}}{p}\right)^{2}
$$

For populations with a limited workforce adjustment $\mathrm{S}$ are used:

$$
N_{1}=\frac{N}{\left(1+\frac{N}{Q}\right)}
$$

With:

- $Z_{\alpha}$ is the value of $Z$ (the first kind risk) corresponding to $\alpha$ for a bilateral situation

- $\alpha$, selected depending on the confidence level $(1-\alpha)$ desired (here $95 \%)$,

- $\Pi$, the expected proportion of subjects with a descriptive characteristic data in the population of subjects with cancer in Morocco. 
$\bullet p$, the deviation of inaccuracy that is accepted on each side of the estimate to make the result;

- $Q$, effective for the general population from which the sample is extracted (target population).

For a desired proportion of occupational exposure $\Pi=50 \%$, a number of farmers in rural areas of Meknes-Tafilalt region $Q=272,037$, an error $\alpha=0.05(5 \%)$ and a standard of vagueness $5 \%$ workforce to be included in the study is: $\mathrm{N}=384$, which was rounded to 400 .

\subsection{Sampling Methods}

The rural sector of the Meknes region includes farms with areas ranging from less than one ha to 100 ha and more. The inclusion of subjects in the study was made respecting the distribution of farms according to the size of the utilized agricultural area (UAA) in the Meknes region. Thus, the distribution of the 400 subjects included in the study was proportional to the number of utilized agricultural area (UAA) for each class (Table 2).

In each community of the 15 communities in the study area, 26 - 27 households were contacted. The investigation was performed at home in the douars and localities from municipalities.

In each contacted household, a person pursuing an activity in the agricultural sector was questioned. After answering the question concerning the area of the holding in which they are currently practicing, eligible persons were classified in one of the classes of UAA. The survey was conducted door to door until the number required for each class is reached. If contacted in the home there were no people in the classes for which enrollment is was not yet reached, even if they exercised an agricultural activity, the nearest home was investigated. It was the same if no person working in the sector was found in the household contacted.

Table 2. Distribution of respondents habitats depending on the size of farms with the agricultural area (UAA).

\begin{tabular}{cccc}
\hline UAA class (ha) & Number holdings (\%) & UAA (\%) & Number of respondents habitats \\
\hline $0-1$ & 22.0 & 2.0 & 8 \\
$1-3$ & 31.2 & 10.4 & 41 \\
$3-5$ & 16.6 & 11.6 & 47 \\
$5-10$ & 17.3 & 21.7 & 87 \\
$10-20$ & 8.7 & 21.5 & 86 \\
$20-50$ & 3.4 & 17.5 & 70 \\
$50-100$ & 0.5 & 6.7 & 26 \\
100 et + & 0.2 & 8.7 & 35 \\
Total & 100.0 & 100.0 & 400 \\
\hline
\end{tabular}




\subsection{Survey Instrument}

The farmers participating in the study answered a questionnaire which was applied by a trained professional. The questionnaire, was comprised of objective questions (yes/no or multiple choice), and subjective questions: questions related to basic socio-demographic data (age, sex, education level of respondents, marital status and monthly household income), to information about the current occupation (job type, operation of surface, speculations, the names of pesticides used, type of equipment used for spraying (knapsack sprayer, backpack sprayer, carried sprayer towed sprayer tank volume, cultures treated with this material, number of days of use annually, surface treated per day, cleaning equipment), personal protection measures taken by farmers during spraying (using waterproof gloves, mask with filter cartridge, protective glasses...), tobacco consumption and the Alcohol and clinical information (personal and family history of cancer and other health problems).

The aim was to obtain information on the workers and the farms, the attitudes and practices of farmers regarding pesticide use, and symptoms following pesticide application to determine the impact of pesticide use on human health.

\subsection{Data Treatment}

The data gathered from the questionnaires were transferred to The statistical analysis was performed with the IBM SPSS Statistics Version 19 software for Windows and EXCEL 2007 .Descriptive analysis of the general characteristics of the study population was performed. The $\left(\chi^{2}\right)$ testing was used to determine possible association between the nominal variables of the study. The T-test was used for the comparison of the means. The level of significance was set at $95 \%(p<0.05)$. The results are presented in graphs and tables and presented using a geographical information system (GIS).

\section{Results}

\subsection{Population Characteristics}

A total of 402 farmers participated in this study, most farmers were involved in market gardening and arboriculture. The respondents were mostly male (90.3\%) and age ranged from 18 - 72 years with an average age of $37.95 \pm 11.06$. Half farmers has a primary or lower educational level $(76.3 \%), 14.8 \%$ had completed secondary educationand $2.5 \%$ have a higher level of education, $1.8 \%$ had attended courses of informal education and $4.8 \%$ Koranic school. Most farmers (76.61) worked in a family agricultural, and $23.19 \%$ worked as workers or tractoristes. Most of the respondents (94.53\%) had been using pesticides for at least 5 years, and $47.73 \%$ for over 20 years. Halfhad never smoked (50.66\%), whereas $47.3 \%$ were ex-smokers and only $30.8 \%$ current smokers. Most respondents (77.33\%) had used pesticides for more than 10 years.

Regarding marital status, $35.5 \%$ of those interviewed were single, $62.3 \%$ married, $1.3 \%$ divorced and $1 \%$ were widowed (Table 3 ).

In all the surveyed towns, arboriculture, cereals, potatoes and onions are the most answered in the crop rotation and acreage of Agricultural Area (UAA). Grain farming 
Table 3. Social and demographic characteristics of the Meknes El Hajeb farmers $(\mathrm{N}=402)$.

\begin{tabular}{|c|c|c|}
\hline Paramètre & Nombre d'agriculteurs & Percentage (\%) \\
\hline Age & $37.95 \pm 11.06$ & \\
\hline \multicolumn{3}{|l|}{ Sexe } \\
\hline men & 363 & 90.3 \\
\hline women & 39 & 9.7 \\
\hline \multicolumn{3}{|l|}{ Education } \\
\hline illiterate & 142 & 35.3 \\
\hline Koranic & 19 & 4.8 \\
\hline Primary & 165 & 41 \\
\hline High school & 59 & 14.8 \\
\hline Higher & 10 & 2.5 \\
\hline \multicolumn{3}{|l|}{ Labor regime } \\
\hline Farmer & 308 & 76.61 \\
\hline worker & 88 & 21.89 \\
\hline Tractoriste & 5 & 1.3 \\
\hline \multicolumn{3}{|l|}{ Year of pesticide use } \\
\hline Up to 5 & 22 & 5.47 \\
\hline $5-10$ & 69 & 17.2 \\
\hline $10-20$ & 119 & 29.6 \\
\hline $20-30$ & 171 & 42.5 \\
\hline$>30$ & 21 & 5.23 \\
\hline \multicolumn{3}{|l|}{ Tabacco smoking } \\
\hline Ex smokers & 190 & 47.3 \\
\hline Never smokers & 88 & 21.9 \\
\hline Smokers & 124 & 30.8 \\
\hline \multicolumn{3}{|l|}{ Marital status } \\
\hline single & & 35.5 \\
\hline married & & 62.3 \\
\hline Divorced & & 1.3 \\
\hline
\end{tabular}

occupies the greatest UAA at all municipalities studied, arboriculture occupies $83.1 \%$ of sown agricultural UAA (Figure 2).

\subsection{Occupational Exposure to Pesticides}

Among the 400 participants who completed questions on use of pesticides, a history of pesticide use was reported by all participants. The proportion of participants having used pesticides on a given crop was $45.9 \%$ on vineyards, $53.9 \%$ on arboriculture, $30.7 \%$ on potatos culture, and less than $7.4 \%$ on other crops. Producers have practiced these treatments for more than 13 years on average (Figure 3 ). 


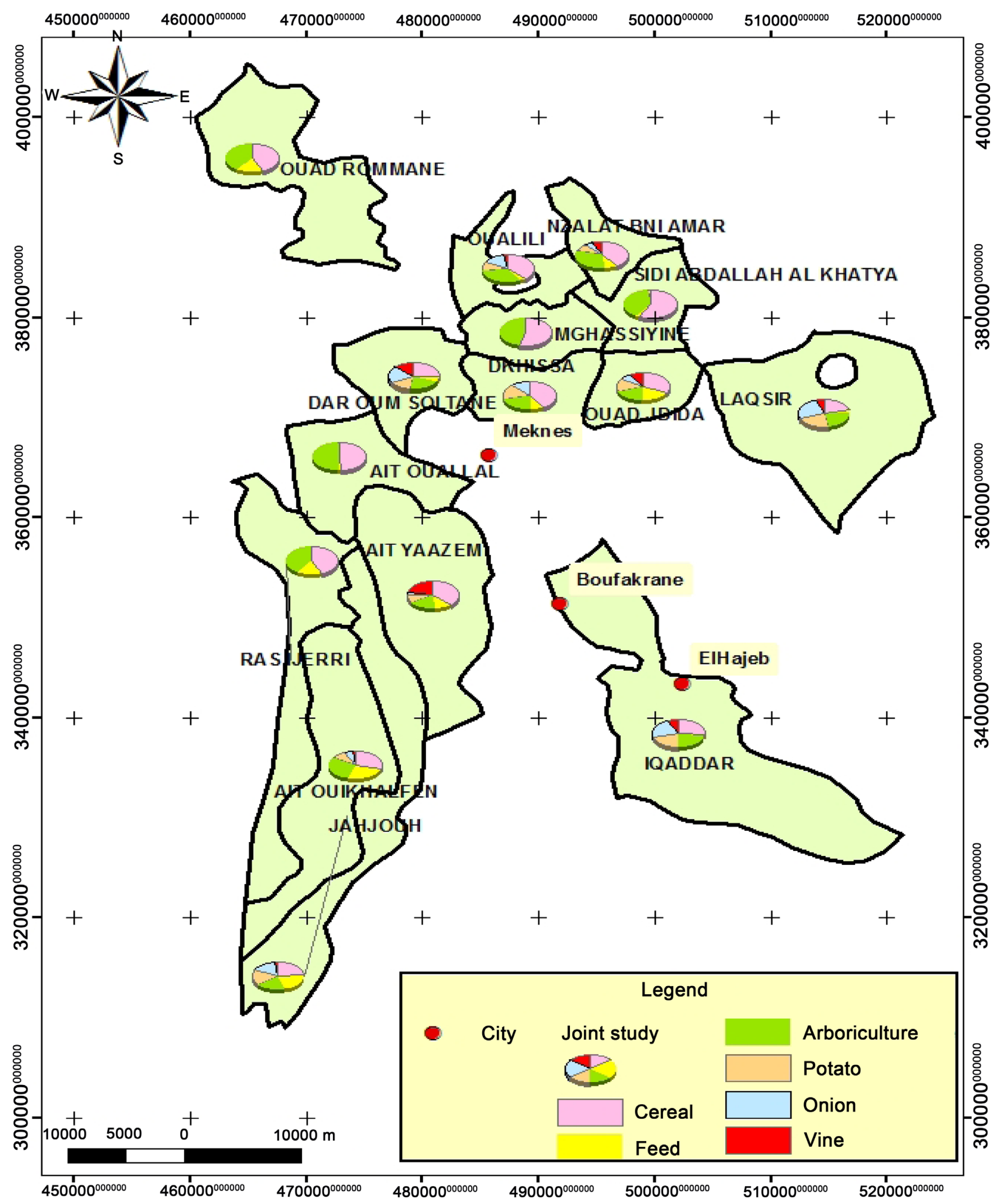

Figure 2. Type of farming in the study area. 


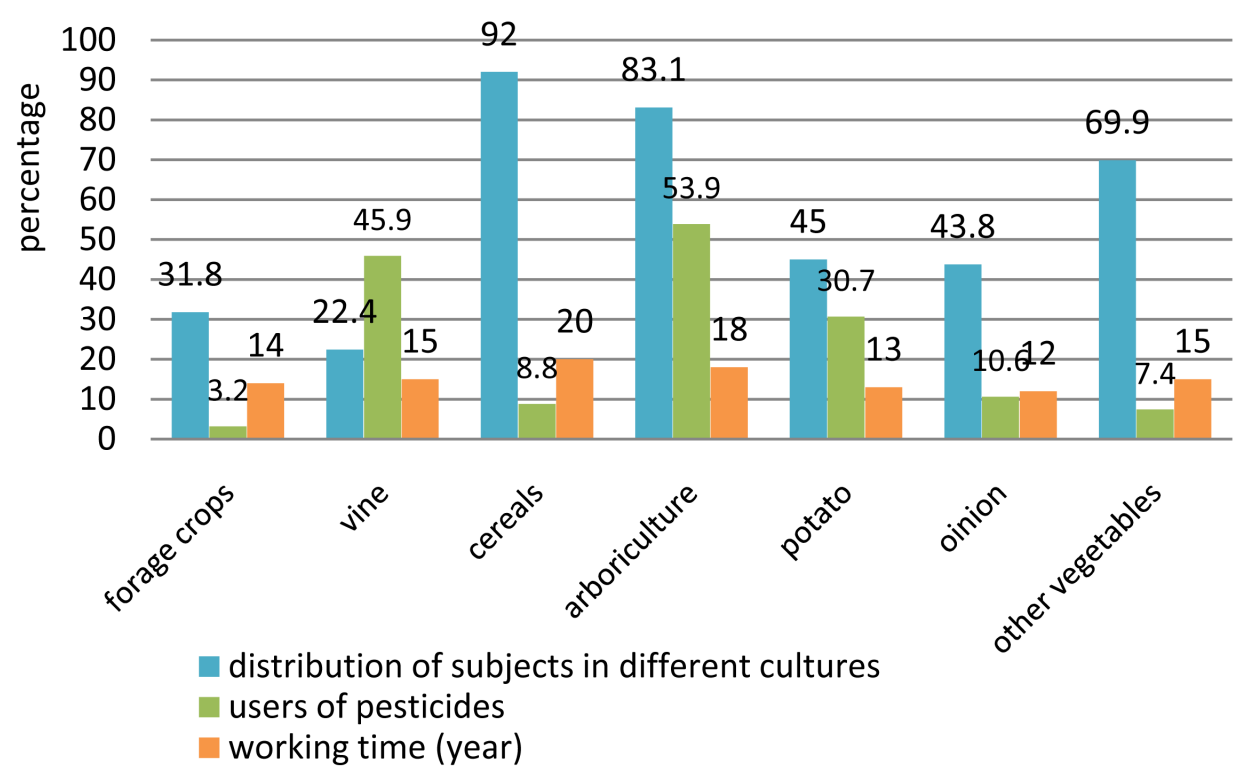

Figure 3. Frequency of cultivation and use of pesticides.

These farmers use spraying equipment often for treatment of the crop: $75.9 \%$ of respondents said they had used. Of these, $89.2 \%$ using backpack sprayers with an average of 28 days of use per year and 21 tanks prepared daily. While for orchards $9.8 \%$ use the trailed atomizer with an average of 24 days of use per year. Table 4 gives details on the different sprays used by the interviewees.

No significant correlation was found between the reporting of adverse symptoms and level of education, years of pesticide use, the use of precautionary measures. However, a significant correlation ( $p=0.003)$ was found between the reporting of adverse symptoms and the use of backpack sprayers. Among farmers who reported adverse symptoms, five (3.73\%) reported Headache, respiratory problems and others.

\subsection{Failure to Take Account of Human Health}

Many surveyed farmers follow a logic of massive pesticide treatments without considering the impact on their health. Indeed, $80.5 \%$ of workers making phytosanitary treatments don't wear protective mask, only $6.3 \%$ door impervious gloves every time. In addition, $41 \%$ of surveyed people reported using other means of precaution, which were mainly gowns and combinations (Table 5).

This lack of awareness could be attributed to illiteracy of some farmers: More than $35.3 \%$ of the samples of people are illiterate (Figure 4). By also the lack of technical knowledge and the lack of communication and trust in advisors agricultural (Agents Techniques and phytiatres centers) contribute to the generalization of these bad practices.

\subsection{Cancer Risk}

Among the subjects interviewed, $75.2 \%$ have used fungicides in their professional lives, $76.7 \%$ have used insecticides, herbicides $77.6 \%, 13.6 \%$ and $20.7 \%$ miticides do not use 


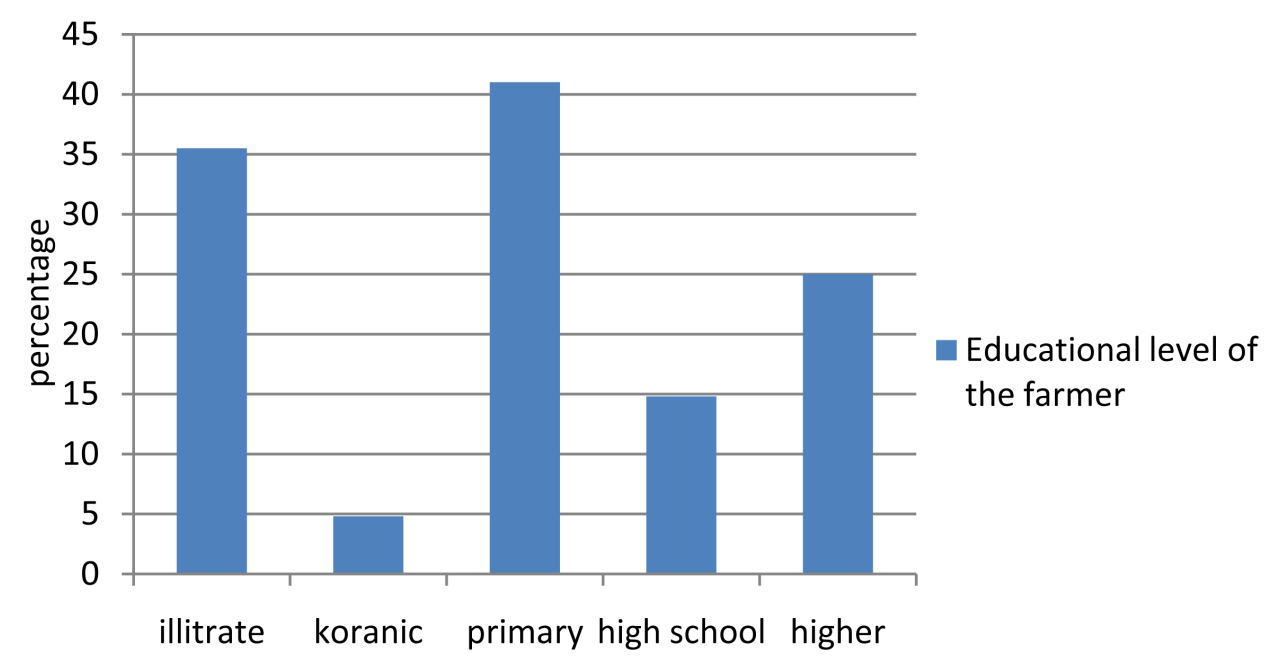

Figure 4. Educational level of surveyed farmers.

Table 4. Distribution of the study population according to the use of spraying equipment.

\begin{tabular}{|c|c|c|c|c|}
\hline & Backpack sprayer & Backpack atomizer & Trailed atomizer & sprayer \\
\hline$\%$ utilisation & 89.2 & 31.6 & 9.8 & 9.8 \\
\hline \multicolumn{5}{|l|}{ Service life (years) } \\
\hline vine & 39 & 9.14 & 11 & 0 \\
\hline orchard & 10.6 & 8.5 & 32 & 11.07 \\
\hline Vegetable crops & 15 & 7.87 & 15 & 14 \\
\hline \multicolumn{5}{|l|}{ Total days of use/year } \\
\hline vine & 28 & 27.5 & 32 & 0 \\
\hline orchard & 33.86 & 29 & 24 & 30.15 \\
\hline Vegetable crops & 23 & 26 & 19 & 24 \\
\hline \multicolumn{5}{|c|}{ Number vats prepared/day } \\
\hline Vine & 21.2 & 74 & 15 & 0 \\
\hline Orchard & 27.79 & 49 & 13 & 10.3 \\
\hline Vegetable crops & 31 & 47 & 25 & 12 \\
\hline
\end{tabular}

Table 5. Use of personal protective devices by the Meknes El Hajeb farmers.

\begin{tabular}{cccc}
\hline Protection measure & impermeable gloves & protective & Eyewear mask \\
\hline No use & 52.4 & 80.5 & 89.3 \\
Sometimes & 41.4 & 17.5 & 8.1 \\
Always & 6.3 & 2.0 & 2.5 \\
\hline
\end{tabular}

product. More than half of producers (57.9\%) recalled products (fungicides, herbicides and insecticides) they have used in their professional lives. The most frequently used are the formulations of deltamethrin, Maneb, malathion, lambdacyhalothrin, chlorothalonil, man coze band. 
The International Agency for Research on Cancer (IARC) assessed and classified the carcinogenicity of some pesticides, Based on toxicological and epidemiological data available. The recent version of this classification (2012) has classified pesticides as-Group 1: Carcinogenic to humans, Group 2A: Probably carcinogenic to humans, Group 2B: Possibly carcinogenic to humans, Group 3: Not classifiable as to its carcinogenicity to humans, Group 4: Probably not carcinogenic to humans In our study a part of pesticides used is classified as to its carcinogenicity risk (Table 6) in the same IARC monograph.

Among the subjects of the investigation, one person reported a personal history of cancer, while $10.5 \%$ reported a family history of cancer. Kinshipevoked for these cancer cases are: uncle (4 cases), Grandparents (3 cases), parents (3 cases), brother(one case), cousin(one case).

A set of farmers (20.6\%) reported having health problems outside the cancer (migraines, rheumatism, diabetes ...). The main health problems are respiratory problems including "allergies" with symptoms such as sneezing, coughing, nose pain, throat irritation, and breathing difficulties (11 farmers), rheumatism (8 farmers). No significant correlation was found between the declaration of these health problems and the level of education, years of pesticide use, and the use of precautionary measures. However, a significant correlation $(p=0.003)$ was observed between the reporting of health problems and use of backpack sprayers. Among the farmers who reported these problems, five $(3.73 \%)$ reported having headaches, and eleven having respiratory problems..

The consumption of alcohol and tobacco to a certain degree had a strong correlation with the return of these health problems $(p=0.0057$ and $p=0.052)$.

\section{Discussion}

In Meknes-El Hajeb region, the broad spectrum of use of pesticides by farmers can cause a variety of environmental contamination situations and expose the operators, workers and surrounding people to treated plots. While the immediate effects of these substances are well known, there is a lack of information about their delayed effects. They may in fact be associated with the development of serious diseases: cancer, neurodegenerative diseases, fertility disorders, respiratory diseases, etc. However, these diseases are multifactorial and can appear many years after exposure to pesticides. It is imperative to know the pattern of pesticide use and the main carcinogens used by farmers in the studied area.

The 402 farmers participating in this study were directly exposed to pesticides, either during solution preparation and/or its application in the field. Almost all (with the exception of nine cases); $90.3 \%$ were men, reflecting the profile for the Moroccan rural population, and similar to the results obtained in other studies in the country [18]. A different profile was found in certain regions of China, where most pesticide applicators were women, being potentially more vulnerable to pesticides [19].

In general, the educational level of the farmers surveyed in this study was low (most have not completed their primary education), similar to other Morocco regions [18] 
Table 6. Carcinogenic pesticides in our study (our survey).

\begin{tabular}{|c|c|c|c|c|}
\hline Active ingredient & Chimical group & $\begin{array}{l}\text { IARC } \\
\text { Class }\end{array}$ & $\begin{array}{l}\text { Frequecy } \\
(\mathrm{n}=402)\end{array}$ & $\begin{array}{c}\text { Percentage } \\
\text { exposition (\%) }\end{array}$ \\
\hline Deltaméthrine & pyrethroids & 3 & 186 & 46.5 \\
\hline Manèbe & Dithiocarbamate & 3 & 63 & 15.7 \\
\hline Malathion & Organophosphate & 3 & 49 & 12.4 \\
\hline Zirame & Dithiocarbamate & 3 & 38 & 9.7 \\
\hline Thirame & Dithiocarbamate & 3 & 34 & 8.4 \\
\hline Dicofol + tetra difon & Organochlorine & 3 & 30 & 7.5 \\
\hline Huile Minérale & & & 11 & 2.7 \\
\hline $\begin{array}{l}\text {-Mineral Oils, Untreated } \\
\text { And Mildly Treated }\end{array}$ & & 1 & & \\
\hline -Mineral Oils, Highly-Refine & & 3 & & \\
\hline Huile Minérale Paraffinique & & 3 & 1 & 0.2 \\
\hline \multicolumn{5}{|l|}{ Peroxyde D’hydrogène } \\
\hline \multirow[t]{2}{*}{ Chlorothalonil } & & 3 & 4 & 0.9 \\
\hline & Chloronitrile & $2 \mathrm{~B}$ & 2 & 0.4 \\
\hline \multicolumn{5}{|l|}{ Captane } \\
\hline Autres (non classé) & Organochlorés & 3 & 2 & 0.4 \\
\hline \multicolumn{5}{|l|}{ 2,4 D (sels d'amine) } \\
\hline \multicolumn{5}{|l|}{ Glyphosate } \\
\hline 2,4 MCPA & Phtalimides & - & 317 & 79 \\
\hline Methomyl & & & 161 & 40 \\
\hline Lambda cyhalothrine & chloro-phénoxy & - & 128 & 32 \\
\hline Clodinafop-Propargyl + & aminophosphanate & - & 145 & 36 \\
\hline Cloquintocet-mexyl & pyrethroids & - & 92 & 23 \\
\hline Mancozeb & Carbamates & - & 92 & 23 \\
\hline \multicolumn{5}{|l|}{ Flusilazol } \\
\hline Paraquat & Dithiocarbamate & - & 68 & 17 \\
\hline Fluzilazole + Carbendazime & Triazole & & 64 & 16 \\
\hline Dimethoate & Dithiocarbamate & - & 64 & 16 \\
\hline Flutriafol & Triazole & - & 60 & 15 \\
\hline Cypermethrin & Organophosphate & - & 52 & 13 \\
\hline Endosulfan & Triazole & - & 96 & 24 \\
\hline Mancozeb & Pyrethroids & - & 20 & 5 \\
\hline Carbendazime & Organochlorin & - & 8 & 2 \\
\hline Abamectin & Dithiocarbamate & - & 16 & 4 \\
\hline \multirow[t]{2}{*}{ others } & Carbamate & - & 40 & 10 \\
\hline & Ivamectins & - & 16 & 4 \\
\hline
\end{tabular}


[20]. This contrasts strongly with situations like France where half of farmers had completed high school (41.7\%) [21], and in the United States $55.8 \%$ of pesticide applicators in New York State had at least 12 years of schooling [22].

Pesticide use requires protective measures to ensure users safety. Farmers in our study appeared to be less aware of the importance of using precautions, and only $6.3 \%$ had used them. Over $80 \%$ of farmers have never used masks or goggles. The same behavior has also been observed in other developing countries [23] [24] [25] [26] where very few producers comply with the rules of hygiene during and after pesticide treatments.

Similar findings about non usage of protective measures amongst farmers have been reported in studies conducted in northen Greece [27] and Indea [28], and also reported in the area of MarjaZerga in Morocco [20], or $89 \%$ of farmers use no precaution during their work.

Non-use of protective equipment may be related to the lack of financial means. The income is spent on satisfying the everyday necessities of the home and on the raising of children. These behaviors increase the risk of poisoning and expose producers to various pathologies. While $41 \%$ of surveyed people reported using other means of precaution, which were mainly gowns and suits, the use of these means, which are relatively cheap, confirms the hypothesis that the choice of means of protection by farmers were influenced by economic considerations.

The survey found that 74 commercial preparations are used, 14 insecticides, 23 fungicides, 26 herbicides, 3 insecticide-acaricide and nematicide 1 . The most frequently used are the formulations of lambdacyhalothrin, chlorothalonil, mancozeb, endosulfan and deltamethrin. Most producers use pyrethroids, organophosphates, organochlorines and carbamates. Among these, few substances classified Group 1, 2A or 2B in the IARC monograph.

Endosulfan, dicofolandcaptan was the three organochlorine that was mentioned to be used during the present study. As these substances is about to beadded to the Stokhholm Convention of Persistent Organic Polluants (POPs) [29], it is worrying that it still was commonly used by the farmers in Morocco.

These are especially mineral oils (Group 1), chlorothalonil (group 2B) and deltamethrin (Group 3), with a proportion of exposure by $2.7 \%$ respectively $0.4 \%$ and $46.5 \%$.

These pesticides used in Meknes, El Hajeb region may therefore expose the user or even the consumer to risk of non mastered poisoning. Furthermore pyrethroids (deltamethrin) have a lethal high acute and chronic toxicity [30] and show an example of toxicity that may affect these farmers. Indeed, deltamethrin is classified carcinogenic to humans and most frequently used. It can cause endocrine disruption, affecting the hormonal system of the body, which can cause increased natal abnormalities, sexual disturbances and failures reproductive; deltamethrin also increases apoptosis in various cancer cells [31].

The survey also revealed that farmers in our study were exposed to organochlorine pesticides which are classified as persistent organic pollutants (POPs) due to their 
ubiquity, persistence and bioaccumulation in the environment [32] [33]. indeed, Their high toxicity to humans and non-target organisms poses significant threats to human health and biodiversity [34].

Epidemiological studies suggest that the exposure to certain pesticides (endosulfan and ziram) increase the risk of developing Parkinson's disease by inhibiting the ubiquitin-proteasome system [35], in addition, l'Endosulfan is an organochlorine pesticide banned in 56 countries because of its high toxicity and environmental impact [36]. And has been included in the list of persistent organic pollutants (POPs) scheduled for elimination [37].

Organophosphates (dimethoate) are among the most toxic pesticides [38]. Exposure to organophosphorus compounds affects the quality of sperm [38]. Furthermore, in some cases, the metabolites are more toxic than the parent compound, thus e.g. malaxon would be 10 to 30 times more toxic than malathion and could induce gene mutations and chromosomal aberrations [39].

Almost all farmers in this study know very well the dangers of the chemicals they work with, but there may other social and economic factors beyond their control. For example, farmers may be well aware of the risks, but they adopt risk practices like or disincentives related to the costs of protective equipment and safe storage or the abusive use of these chemicals to increase production.

In our study, more than $20.6 \%$ of farmers have reported health problems, similar to the findings of Racena et al. (60\%; mostly backpack sprayer use) and Joan et al in central florida [40]. We did found a correlation between the reporting of health problems and the applications of pesticides with knapsack sprayers, used by $89.2 \%$ of the farmers. This technology, generally used on small farms, may increase the risk of developing side effects, especially if the equipment is not maintained, the slurry of the pesticide may sink on the back of the worker during treatments cultures (Figure 5).

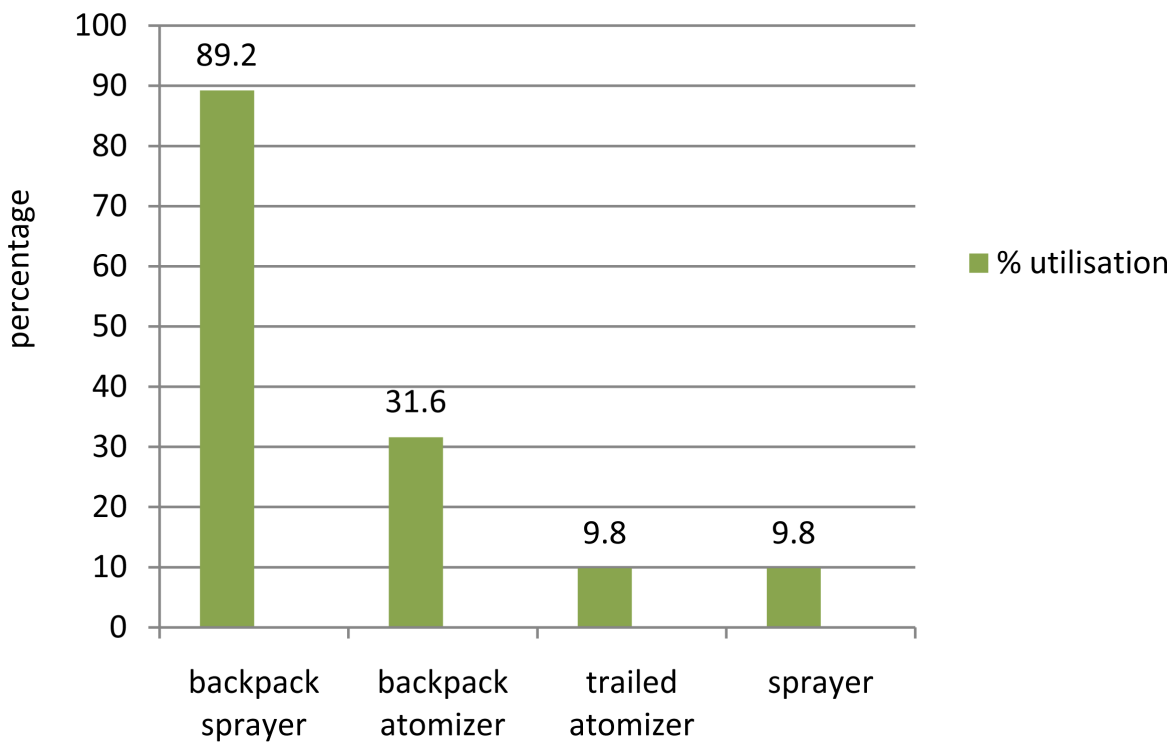

Figure 5. Distribution of the population: a study based on the use of spraying equipment. 
We also found a significant correlation between the consumption of alcohol and tobacco and reporting of health problems.

Based on the results found in the context of this work we can confirm that pesticide exposure may play a role in causing respiratory problems and asthma. Meanwhile the epidemiological studies that examines the effect of some pesticides Health shows that the herbicide paraquat, was associated with a decrease in lung function [41]. Thus Organophosphates, carbamates and organochlorines insecticides have been associated with asthma in population-based studies [42].

\section{Conclusions}

This study establishes a diagnosis of farmers' exposure to carcinogenic chemicals in the region of Meknes in Morocco El Hajeb. Although we are based on a random sample, farmers in this study appeared to be typical of farmers in the Moroccan context, this suggests a public health problem that may be spread in the country.

At this stage of our study, we could not assess the exposure of farmers to pesticides, however, we found the existence of a risk of asthmatic and allergic respondents working in tree crops and potatoes, that use a lot pesticides including fungicides. The survey, conducted as part of this work, has identified the formulations classified as carcinogens according to IARC monograph on pesticides used in market gardening and arboriculture and appreciates the dangers they pose to humans. The farmers surveyed at the Meknes-El Hajeb region didn't receive coaching or training. They buy the pesticides on the local market which they know neither toxicity nor the mode of use. The methods of use, lack of appropriate protective gear are aggravating risk factors for farmers. Based on the results obtained, it was easy to give to different partners an idea on exhibitions that they could be harmful to health. This is a necessary step in the implementation of preventive measures against the risk factors linked to cancer in the farms at the local, regional and national levels.

\section{Acknowledgements}

We wish to express our sincere gratitude to the University Sidi Mohamed Ben Abdellah, Faculty of Medicine and Pharmacy, Laboratory of Epidemiology, clinical Research and Community Health who supported this work financially and for the support and guidance they provided during the conduct of this study. The following organizations also deserve recognition Lalla Salma Foundation for Prevention and Treatment of Cancer, University Moulay Ismail, Faculty of Sciences, Meknes for active coordination of this study.

\section{Ethics (and Consent to Participate)}

Not applicable.

\section{Consent for Publication}

Not applicable. 


\section{Availability of Data and Materials}

The data will not be shared.

\section{Competing Interests}

The authors declare that they have no competing interests.

\section{Funding}

This work was financed by University Sidi Mohamed Ben Abdellah, Faculty of Medicine and Pharmacy through university research budget.

\section{Authors' Contributions}

IB: Carried out data collection, analysis and results interpretation, she also drafted the manuscript and was the corresponding author. MA: Carried out the study design, field survey, data collection, analysis of results. KER: Carried out the study design, field survey, data collection, participated in the statistical data analysis and supported drafting and revision of the manuscript. $\mathrm{CN}$ : Participated in the study design, statistical data analysis and supported interpretation. He was also involved in revision of the manuscript. SEJ: Participated in the statistical data analysis and supported drafting and revision of the manuscript. All authors read and approved the final manuscript.

\section{References}

[1] Morocco Crop Life (2011) Les statistiques des importations des produits phytosanitaires au Maroc. http://croplife.ma/etudes/

[2] Hormatallah, A. (2011) Système d'Approvisionnement, de Distribution, de Stockage et du Transport des Pesticides au Maroc, Projet FAO/TCP/MOR/3303. Atelier de travail 20-22/ 12/2011. Rabat.

[3] El Ouilani, B. (2011) Le marché des produits phytopharmaceutiques au Maroc. Agriculture du Maghreb, 52, 78-81.

[4] Pimentel, D., Acquay, H., Biltonen, M., Rice, P., Silva, M., Nelson, J., Lipner, V., Giordano, S., Horowitz, A. and D'Amore, M. (1992) Environmental and Human Costs of Pesticide Use. Bioscience, 42, 750-760. https://doi.org/10.2307/1311994

[5] Samuel, O. and Saint-Laurent, L. (2001) Guide de prévention pour les utilisateurs de pesticides en agriculture maraîchère. Institut de recherche en santé et en sécurité de travail du Québec (IRSST), 85 p.

[6] Koutros, S., Alavanja, M.C.R., Lubin, J.H., Sandler, D.P., Hoppin, J.A., Lynch, C.F., Knott, C., Blair, A. and Freeman, L.E.B. (2010) An Update of Cancer Incidence in the Agricultural Health Study. Journal of Occupational and Environmental Medicine, 52, 1098-1105. https://doi.org/10.1097/JOM.0b013e3181f72b7c

[7] Bladi, I., Bouvier, G. and Cordier, S. (2013) Pesticides. Health Effects: Review Report, National Institute of Health and Medical Research (INSERM).

[8] Alavanja, M.C. and Bonner, M.R.O. (2012) Occupational Pesticide Exposures and Cancer Risk: A Review. Journal of Toxicology and Environmental Health, Part B: Critical Reviews, 15, 238-263. https://doi.org/10.1080/10937404.2012.632358 
[9] Deguine, J.P., Ferron, P. and Russell, D. (2008) Crop Protection from Agrochemistry to Agroecology. Enfield Science Publishers, XXVI, 190 p.

[10] Cormis, L. (1994) Qualité de l'environnement, pesticides et pratiques agricoles enjeux et contractions des procédures de contrôle. Etud. Rech. Syst. Agraires Dév, 28, 65-72.

[11] Abhilash, P.C. and Singh, N. (2009) Pesticide Use and Application: An Indian Scenario. Journal of Hazardous Materials, 165, 1-12. https://doi.org/10.1016/j.jhazmat.2008.10.061

[12] Goff, L., André, V., Lebailly, P., Pottier, D., Périn, F., Périn, O. and Gauduchon, P. (2005) Seasonal Variations of DNA-Adduct Patterns in open field farmers handling pesticides. Mutation Research, 587, 90-112. https://doi.org/10.1016/j.mrgentox.2005.05.013

[13] Van Maele-Fabry, G., Lantin, A.C., Hoet, P. and Lison, D. (2010) Childhood Leukaemia and Parental Occupational Exposure to Pesticides: A Systematic Review and Meta-Analysis. Cancer Causes and Control, 21, 787-809. https://doi.org/10.1007/s10552-010-9516-7

[14] Association lalla Salma de lute contre le cancer (2010) Synthèse du plan nationale de prévention et de contrôle du cancer 2010-2019.

http://www.sante.gov.ma/Documents/Synthese_PNPCC_2010-1019.pdf

[15] Idrissi, M., Aït Daoud, N., Ouammi, L., Rhalem, N., Soulaymani, S. and Soulaymani Bencheikh, R. (2010) Intoxication aigüe par les pesticides: Données du Centre Anti Poison du Maroc (1989-2007). Toxicologie Maroc, 4, 5-7.

[16] Centre antipoison du Maroc (2011) Rapport Annuel 2011 de la toxicovigilance, épidémiologie des décès par empoisonnement au Maroc Les Décès Toxiques. Données du Centre Antipoison et de Pharmacovigilance du Maroc (1992-2009).

[17] Ouammi, L., Rhalem, N., Aghandous, R. and Semlali, I. (2009) Profil épidémiologique des intoxications au Maroc de 1980 à 2007. Toxicologie Maroc, 1, 8-13.

[18] Eddaya, T., Boughdad, A., Becker, L., Chaimbault, P. and Zaid, A. (2015) Utilisation et risques des pesticides en protection sanitaires de la menthe verte dans le centre sud du Maroc. Journal of Materials and Environmental Science, 6, 656-665.

[19] Zhang, X., Zhao, W., Jing, R., Wheeler, K., Smith, G.A., Stallones, L. and Xiang, H. (2011) Work-Related Pesticide Poisoning among Farmers in Two Villages of Southern China: A Cross-Sectional Survey. BMC Public Health, 11, 429-436. https://doi.org/10.1186/1471-2458-11-429

[20] Ayadi-Hajji, H. () Outils de Gestion de la Pollution Phytosanitaires diffuse d'un Territoirre : cas d'Application à la zone humide Ramsar de la Merja Zerga au Maroc. PhD Thesis, University Paul Valéry, Montepllier.

[21] Baldi, I., Robert, C., Piantoni, F., Tual, S., Bouvier, G., Lebailly, P. and Raherison, C. (2014) Agricultural Exposure and Asthma Risk in the AGRICAN French Cohort. International Journal of Hygiene and Environmental Health, 217, 435-442. https://doi.org/10.1016/j.ijheh.2013.08.006

[22] Stokes, L., Stark, A., Marshall, E. and Narang, A. (1995) Neurotoxicity among Pesticide Applicators Exposed to Organophosphates. Occupational and Environmental Medicine, 52, 648-653. https://doi.org/10.1136/oem.52.10.648

[23] Wade, C.S. (2003) L'utilisation des pesticides dans l'agriculture périurbaine et son impact sur l'environnement. University of Cheikh Anta Diop, Dakar.

[24] Williamson, S., Ball, A. and Pretty, J. (2008) Trends in Pesticide Use and Drivers for Safer Pest Management in Four African Countries. Crop Protection, 27, 1327-1234. https://doi.org/10.1016/j.cropro.2008.04.006

[25] Akhabuhaya, J. (2005) Needs for Pesticide Safety Outreach Programmes in Developing Countries: A Tanzania Example. African Newsletter on Occupational Health and Safety, 15, 
68-70.

[26] Yassin, M.M., Abu, M.T.A. and Safi, J.M. (2002) Knowledge, Attitude, Practice, and Toxicity Symptoms Associated with Pesticide Use among Farm Workers in the Gaza Strip. Occupational and Environmental Medicine, 59, 387-393. https://doi.org/10.1136/oem.59.6.387

[27] Damalas, C.A., Georgiou, E.B. and Theodorou, M.G. (2006) Pesticide Use and Safety Practices among Greek Tobacco Farmers: A Survey. International Journal of Environmental Health Research, 16, 339-348. https://doi.org/10.1080/09603120600869190

[28] Mancini, F., Van Bruggen, A.H.C., Jiggins, J.L.S., Ambatipudi, A.C. and Murphy, H. (2005) Acute Pesticide Poisoning among Female and Male Cotton Growers in India. International Journal of Occupational and Environmental Health, 11, 221-232. https://doi.org/10.1179/oeh.2005.11.3.221

[29] Kohler, P.M., Roemer-Mahler, A. and Templeton, J. (2008) Summary of the Fourth Meeting of Persistant Organic Pollutants Review Committee of the Stockholm Convention. Earth Negotiations Bulletin, 15, 13-17.

[30] Alavanja, M.C.R., Samanic, C., Dosemecil, M., Lubin, J., Tarone, R., Lynch, C.F., Knott, C., Thomas, K., Hoppin, J.A., Barker, J., Coble, J., Sandler, D.P. and Blair, A. (2003) Use of Agricultural Pesticides and Prostate Cancer Risk in the Agricultural Health Study Cohort. American Journal of Epidemiology, 157, 800-814. https://doi.org/10.1093/aje/kwg040

[31] Chi, C.C., Chou, C.T., Liang, W.Z. and Jan, C.R. (2014) Effect of the Pesticide, Deltamethrin, on $\mathrm{Ca}^{2+}$ Signaling and Apoptosis in OC2 Human Oral Cancer Cells. Drug and Chemical Toxicology, 37, 25-31. https://doi.org/10.3109/01480545.2013.806528

[32] Jones, K.C. and de Voogt, P. (1999) Persistent Organic Pollutants (POPs): State of the Science. Environmental Pollution, 100, 209-221. https://doi.org/10.1016/S0269-7491(99)00098-6

[33] Willett, K.L., Ulrich, E.M. and Hites, R.A. (1998) Differential Toxicity and Environmental fates of Hexachlorocyclohexane Isomers. Environmental Science \& Technology, 32, 2197 2207. https://doi.org/10.1021/es9708530

[34] Jiang, Y.F., Wang, X.T., Jia, Y., Wang, F., Wu, M.H., Sheng, G.Y. and Fu, J.M. (2009) Occurrence, Distribution and Possible Sources of Organochlorine Pesticides in Agricultural Soil of Shanghai, China. Journal of Hazardous Materials, 170, 989-997. https://doi.org/10.1016/j.jhazmat.2009.05.082

[35] Wang, X.F., Li, S., Chou, A.P. and Bronstein, J.M. (2006) Inhibitory Effects of Pesticides on Proteasome Activity: Implication in Parkinson's Disease. Neurobiology of Disease, 1, 198205. https://doi.org/10.1016/j.nbd.2006.02.012

[36] PAN Asia Pacific (2008) STOP Endosulfan. Stop Pesticides Poisonings. http://www.panap.net/en/p/post/pesticides-campaigns-npud/122

[37] UNEP (2009) Risk Profile on Endosulfan. Geneva.

[38] Perry, M.J., Venners, S.A., Chen, X., Liu, X., Tang, G., Xing, H., Barr, D.B. and Xu, X. (2011) Organophosphorous Pesticide Exposures and Sperm Quality. Reproductive Toxicology, 31, 75-79. https://doi.org/10.1016/j.reprotox.2010.08.006

[39] US EPA (US Environmental Protection Agency) (2006) Reregistration Eligibility Decision (RED) for Malathion.

[40] Recena, M.C.P., Caldas, E.D., Pires, D.X. and Pontes, E.R.J.C. (2006) Pesticides Exposure in Culturama, Brazil-Knowledge, Attitudes and Practices. Environmental Research, 102, 230-236. https://doi.org/10.1016/j.envres.2006.01.007 
[41] Dalvie, M.A., White, N., Raine, R., Myers, J.E., London, L., Thompson, M. and Chris-Tiani, D.C. (1999) Long-Term Respiratory Health Effects of the Herbicide, Paraquat, among Workers in the Western Cape. Occupational and Environmental Medicine, 56, 391-396. https://doi.org/10.1136/oem.56.6.391

[42] Hernández, A.F., Parrón, T. and Alarcón, R. (2011) Pesticides and Asthma. Current Opinion in Allergy and Clinical Immunology, 11, 90-96.

https://doi.org/10.1097/ACI.0b013e3283445939

\section{List of Abbreviations:}

AMIPHY: Moroccan Association of Importers traders and formulators of pesticides SPSS: Statistical Package for the Social Sciences

GIS: Geographical Information System

IARC: International Agency for Research on Cancer

POP: Persistent Organic Polluants

UAA: Utilized Agricultural Area

Submit or recommend next manuscript to OALib Journal and we will provide best service for you:

- Publication frequency: Monthly

- 9 subject areas of science, technology and medicine

- Fair and rigorous peer-review system

- Fast publication process

- Article promotion in various social networking sites (LinkedIn, Facebook, Twitter, etc.)

- Maximum dissemination of your research work

Submit Your Paper Online: Click Here to Submit

Or Contact service@oalib.com 